ANDRZEJ KOBYLIŃSKI

\title{
SPRAWOZDANIE Z KONFERENCJI NAUKOWEJ NT. OBLICZA NIHILIZMU WE WSPÓŁCZESNEJ FILOZOFII I KULTURZE, UNIWERSYTET KARDYNAŁA Stefana WySZyńSKIEgo, WarSZaWa, 23 MAJa 2018 R.
}

23 maja 2018 roku na Wydziale Filozofii Chrześcijańskiej Uniwersytetu Kardynała Stefana Wyszyńskiego w Warszawie miało miejsce sympozjum nt. Oblicza nibilizmu we wspótczesnej fllozofii $i$ kulturze. Konferencja została zorganizowana przez Sekcję Etyki, która stanowi jednostkę organizacyjną tego wydziału. Otwarcia konferencji dokonał ks. prof. dr hab. Ryszard Moń, były dyrektor Instytutu Filozofii Uniwersytetu Kardynała Stefana Wyszyńskiego w Warszawie. W swoim wystąpieniu zwrócił on uwagę na związek obecnego sympozjum z innymi projektami badawczymi, które były realizowane przez Sekcję Etyki na przestrzeni ostatnich kilkunastu lat.

Jedną z takich inicjatyw był projekt badawczy nt. Dziedzictwo wspótczesnej etyki. Badania prowadzone w ramach tego projektu opierały się na współpracy czterech ośrodków uniwersyteckich: Akademii Ignatianum w Krakowie, Uniwersytetu im. Adama Mickiewicza w Poznaniu, Uniwersytetu Mikołaja Kopernika w Toruniu i Uniwersytetu Kardynała Stefana Wyszyńskiego w Warszawie. Innym projektem były ogólnopolskie konwersatoria z cyklu Styczeń-ŚlipkoTischner. Inspiracje chrześcijańskie w etyce, w których uczestniczyli przedstawiciele wielu krajowych ośrodków naukowych. Natomiast w międzynarodowym projekcie badawczym nt. Filozofia praw cztowieka brali udział naukowcy z Czech, Niemiec, Polski i Słowacji.

Prof. Moń stwierdził, że problem obecności nihilizmu we współczesnej filozofii i kulturze jest bardzo aktualny. Pojęcie nihilizmu może mieć znaczenie religijne, polityczne, etyczne. Analizy dotyczące fenomenu nihilizmu są prowadzone w ramach różnych tradycji 
filozoficznych. Niezwykle inspirujące diagnozy tego zjawiska zostały wypracowane m.in. w takich krajach, jak Niemcy, Francja i Włochy.

Pierwszej sesji przewodniczył dr Jarosław Kucharski z Akademii Ignatianum w Krakowie. Obrady rozpoczęły się od wystąpienia dr Anny Szklarskiej z Uniwersytetu Jagiellońskiego, która wygłosiła referat nt. Nadcztowiek versus ostatni cztowiek, czyli problem nibilizmu w filozofii Nietzschego. Prelegentka podkreśliła, że nadczłowiek i ostatni człowiek są fundamentalnymi figurami filozofii Fryderyka Nietzschego. Kim jest ostatni człowiek? To postać, która zawiera $\mathrm{w}$ sobie minimum istoty człowieczeństwa. Ostatni człowiek jest zamknięty na wartości wyższe i towarzyszy mu przekonanie, że potęga swej woli panuje nad światem. Pytania, które stawia, są ironiczne i pogardliwe. Pozostaje on w opozycji do tego wszystkiego, co wielkie, piękne i wzniosłe. Ostatni człowiek nie jest konkretną jednostką, ale stanem ludzkiego ducha i umysłu. Kim jest natomiast nadczłowiek? To personifikacja woli mocy. Nietzsche przeciwstawia go ostatniemu człowiekowi. Nadczłowiek odrzuca gnuśność i bezsens. Źródłem jego nadziei jest idea wiecznego powrotu - wszystko, co się wydarza, wiecznie powraca. Przeciwieństwem myśli o wiecznym powrocie jest pustka i nicość.

Drugi referat nt. Akceptacja czy przezwyciężenie nibilizmu? Moralne implikacje „smierci Boga” zaprezentował ks. dr hab. Andrzej Kobyliński z Uniwersytetu Kardynała Stefana Wyszyńskiego w Warszawie. Stwierdził on, że doświadczenie różnych przejawów nihilizmu należy do specyfiki naszej obecnej Zeitheimat - ojczyzny w czasie. Nihilizm to inaczej „śmierć Boga”, czyli rozpad tradycyjnego fundamentu moralności i kultury. Mówiąc językiem Nietzschego, to „odpętanie ziemi od jej słońca". Prelegent ukazał w swoim wystąpieniu problem akceptacji bądź przezwyciężenia nihilizmu w interpretacji Martina Heideggera, Gianniego Vattima i Vittoria Possentiego.

Dla Heideggera nihilizm jest nieuniknionym przeznaczeniem myśli zachodniej, która narodziła się u Greków. Jest on wewnętrzną niezdolnością metafizyki, aby myśleć właściwie o byciu - aby rozpoznać różnicę ontologiczną jako różnicę między byciem a bytem. Dla 
autora dzieła Bycie i czas nihilizm i metafizyka są dwoma obliczami tego samego fenomenu. Heidegger twierdził, że trzeba zaakceptować nihilistyczne przeznaczenie naszej epoki i panowanie techniki jako formy współczesnego świata. Na czym polega specyfika stanowiska Vattima? Odrzucił on potoczne rozumienie nihilizmu jako akceptacji całkowitej anarchii i destrukcji moralnej oraz nie zgodził się na utożsamienie nihilizmu z przekonaniem o nicości tego, co istnieje. W swojej interpretacji nawiązuje w dużym stopniu do nihilizmu twórczego i spełnionego, głoszącego potrzebę nie tyle przezwyciężenia nihilizmu, ile akceptacji świadomości nihilistycznej - rezygnacji z woli narzucania sensu i znaczenia rzeczom. Natomiast według Possentiego nihilizm, antyrealizm i zapomnienie prawdy bycia stanowią swego rodzaju triadę wzajemnie przenikających się elementów. Żeby przezwyciężyć nihilizm, trzeba powrócić do klasycznej filozofii bytu, następnie do personalistycznej wizji człowieka.

Kolejnym wystąpieniem był referat dr. Jana Wasiewicza z Uniwersytetu Artystycznego w Poznaniu nt. Czy wspótczesna kultura pamięci jest nibilistyczna? Prelegent stwierdził, że obecnie żyjemy w epoce upamiętniania. Na całym świecie powstają nowe pomniki, miejsca pamięci, centra badań historycznych. Wielu ludzi szuka swoich korzeni rodzinnych. W różnych krajach prowadzi się badania nad pamięcią zbiorową i coraz bardziej rozprzestrzeniają się praktyki kommemoratywne. W konsekwencji tych zmian także w relacjach między państwami coraz większą rolę odgrywa polityka historyczna, polityka pamięci. Każda kultura jest kulturą pamięci. Co sprawia, że obecnie troska o pamięć stała się szczególnie intensywna? Jednym z powodów jest demokratyzacja historii, która dokonuje się na naszych oczach. Kolejną przyczyną jest potrzeba konstruowania stabilnych tożsamości w obliczu tożsamościowej płynności. Swego rodzaju modę na pamięć historyczną wzmacnia także niepewność przyszłości i kryzys idei postępu.

Jeśli zgodzimy się z konstatacją Pierre’a Nory, francuskiego historyka pochodzenia żydowskiego, że mówimy tak dużo o pamięci, ponieważ tak niewiele jej zostało, oraz zgodzimy się także, że ideą 
łączącą różne znaczenia nihilizmu jest idea braku - tam, gdzie coś winno być, znajdujemy nicość - to wtedy dość uprawniony wydaje się wniosek, że współczesna kultura pamięci ma rys nihilistyczny. Obecnie istnieje nihilizm kultury pamięci, który polega na dojmującej świadomości niemożliwości naprawienia wyrządzonych krzywd. Istotą tak rozumianego nihilizmu jest przekonanie, że minione cierpienia nie dadzą się naprawić.

Po przerwie kawowej rozpoczęła się następna sesja, której przewodniczył ks. dr Jacek Meller z Uniwersytetu Kardynała Stefana Wyszyńskiego w Warszawie. Pierwszy referat w tej części obrad zaprezentował dr Jarosław Kucharski nt. Nibilizm i kontraktualizm aspekty semantyczne $i$ etyczne. Zauważył on, że na przestrzeni dwóch ostatnich stuleci zostały wypracowane różne definicje nihilizmu, ukierunkowane na konkretne rozumienie tego zjawiska. Desygnatami tego pojęcia są różne postawy, zachowania, wartości. Jednym ze współczesnych autorów, tworzących nowe modele etyczne w kontekście kultury nihilistycznej, jest amerykański myśliciel Thomas Scanlon. Jego propozycja dotyczy możliwości zbudowania etyki niezależnej od fundamentu metafizycznego. Punktem wyjścia tak rozumianej etyki jest następujące pytanie: co jesteśmy winni sobie nawzajem? Scanlon twierdzi, że ludzie dążą do tłumaczenia swego zachowania w kategoriach moralnych. Jego etyka odwołuje się przede wszystkim do rozsądku umawiających się podmiotów, rezygnując z jakichkolwiek założeń o charakterze metafizycznym.

Drugim wystąpieniem był referat prof. UKSW dr hab. Ewy Podrez z Uniwersytetu Kardynała Stefana Wyszyńskiego w Warszawie nt. Nibilizm jako zachęta do odkrywania etyki. Prelegentka skupiła swoją uwagę na egzystencjalnym wymiarze nihilizmu. Stwierdziła, że należy nie tyle szukać ostatecznych rozstrzygnięć, ile zastanawiać się nad tym, w jaki sposób problematyka dotycząca nihilizmu może wpłynąć na filozoficzny namysł nad moralnością. Nihilizm dotyczy człowieka, jego poznania, wartościowania, decyzji, a więc tego, kim chce i kim powinien być. Człowiek, by istnieć wartościowo, musi mieć poczucie sensu życia. A to wymaga aktywnego uczestnictwa 
jednostki w świecie. Proces ten zachodzi w czasie, w którym na indywidualne i zbiorowe wybory nakładają się różne zewnętrzne uwarunkowania. Bywa, że prowadzą one do klęski, tragedii, a nawet do samozagłady. W tych granicznych sytuacjach człowiek dotyka nicości, a więc stanu, w którym uświadamia sobie nie tyle fakt, że wartości tracą swoją ważność, ile że jego życie jest kruche, a los nieprzewidywalny.

Trzeci referat wygłosił dr hab. Piotr Bartula z Uniwersytetu Jagiellońskiego nt. „My" $i$ „Nic”. Punktem wyjścia tego wystąpienia była teza Arystotelesa, że człowiek jest $\mathrm{z}$ natury istotą społeczną, stworzoną do istnienia w teleologicznym państwie. Opinia Arystotelesa wydaje się na pierwszy rzut oka oczywista, jednakże w rzeczywistości taką nie jest. Przeczą temu liczni anarchiści i nihiliści, którzy przynależność do politycznej i aksjologicznej wspólnoty mają za nic. I odwrotnie: państwo i społeczeństwo też ma ich za nic. Mówca z Krakowa zaprezentował galerię kreatywnych anarcho-nihilistów: od Diogenesa z Synopy po Witolda Gombrowicza.

Po dyskusji i przerwie obiadowej rozpoczęła się trzecia sesja, której przewodniczyła dr Anna Szklarska. Pierwszy referat zaprezentował ks. dr Roman Tomanek z Uniwersytetu Kardynała Stefana Wyszyńskiego w Warszawie nt. Logiki nibilistyczne. W swoim wystąpieniu skoncentrował się on na podstawowych założeniach przyjmowanych przy budowaniu nihilistycznych rachunków zdań. Czym są logiki nihilistyczne? To pewne nieklasyczne rachunki (systemy, teorie) logiczne, które nawiązują do tzw. nihilistycznej koncepcji prawdy Tadeusza Kotarbińskiego - zdanie „prawdą jest, że "p «" jest równoznaczne z samym zdaniem „p”. W logikach nihilistycznych odrzuca się podstawowe założenia klasycznej logiki dwuwartościowej. Nihilistyczne rachunki zdań są tworzone metodą aksjomatyczną i odwołują się do współczesnych deflacyjnych teorii prawdy. Na czym polega deflacjonizm? Nie jest on pojedynczą teorią, lecz zespołem koncepcji, wyrastających z pewnych wspólnych intuicji, które zakładają, że predykat prawdy jest w pewnym sensie „niesubstancjalny” czy też 
„metafizycznie neutralny”. W konsekwencji prawda nie ma „natury”, wymagającej analizy o charakterze naukowym.

Drugi referat w tej części obrad wygłosił dr Jacek Frydrych z Katolickiego Uniwersytetu Lubelskiego Jana Pawła II nt. Problem amoralizmu. Wnawiqzaniu do powieści J. Littella „Easkawe”. Przedmiotem tego wystąpienia było zagadnienie amoralizmu, które stanowi poważne wyzwanie dla etyki. Prelegent dokonał charakterystyki amoralizmu z perspektywy wypowiedzi bohatera i jednocześnie narratora książki amerykańskiego pisarza Jonathana Littella pt. Łaskawe, która została opublikowana w 2006 roku. Powieść ukazuje kulisy Zagłady i rolę, jaką w jej przygotowaniu odegrali technokraci i eksperci: prawnicy, ekonomiści i świetnie wykwalifikowana kadra administracyjna. Czym jest amoralizm? To jedno ze stanowisk etycznych w szeroko rozumianej filozofii moralności. Fenomen amoralizmu stanowi jedną z postaci nihilizmu. Amoralizm w wersji ontologicznej oznacza stanowisko filozoficzne, które wyklucza istnienie moralności jako odrębnego zespołu faktów, własności i wartości. Amoralizm w wersji epistemologicznej jest formą akognitywizmu, tzn. zakłada, że moralność jest niepoznawalna. Amoralizm w wersji etycznej ma charakter aksjologiczno-normatywny. Amoralistą praktycznym jest osoba, której nie można przypisać żadnej sprawczości moralnej. Amoralista kwestionuje standardy moralne i krzywdzi innych ludzi.

Kolejny referat zaprezentował ks. dr Jacek Meller nt. Poglady proeutanatyczne jako konsekwencja negacji wartości. Stwierdził on, że różne badania socjologiczne, przeprowadzone w naszym kraju na przestrzeni ostatni lat, wykazały poparcie społeczne dla legalizacji eutanazji na poziomie $40-80$ proc. Poziom poparcia zmienia się w zależności od grupy społecznej, wieku, wykształcenia itp. W niektórych badaniach odróżnia się akceptację prawnej legalizacji eutanazji czynnej od akceptacji prawnej legalizacji samobójstwa wspomaganego. $\mathrm{Z}$ badań wynika, że religijność mierzona intensywnością praktyk religijnych wpływa na sprzeciw wobec eutanazji. Zdecydowanymi przeciwnikami skracania życia na życzenie są m.in. osoby zaangażowane w ruch hospicyjny. 
Czwartym wystąpieniem w tej części obrad był referat ks. mgr. Branislava Čanigi z Trnavskiej univerzity v Trnave nt. St. Augustine's Unquiet Heart and his Passion for Truth as a Response to Human Nothingness and Spiritual Emptiness. Prelegent ze Słowacji poddał analizie różne przejawy kryzysu intelektualnego i duchowego świata zachodniego. Odwołał się m.in. do sporu o chorobę, cierpienie i śmierć małego chłopca Alfiego Evansa z Wielkiej Brytanii na początku 2018 roku. Współczesny nihilizm nie jest tylko sporem intelektualnym, ale dotyczy także praktyki życia moralnego konkretnych ludzi i społeczeństw. Jedną z ciekawych diagnoz obecnych problemów egzystencjalnych ludzi Zachodu wypracował włoski myśliciel Luigi Giussani, który zwracał uwagę na potrzebę doświadczenia religijnego w życiu ludzi. Inspirujące analizy współczesnej mentalności nihilistycznej można znaleźć także w dziełach austriackiego filozofa i teologa Emericha Coretha. Jego zdaniem, szukając lekarstwa na pustkę i nicość, warto dzisiaj powracać do myśli św. Augustyna, który był przekonany o istnieniu prawdy niezależnej od czasu i przestrzeni.

Kolejny referat wygłosił mgr Wiesław Setlak z Uniwersytetu Rzeszowskiego nt. Nibilista (?) Albert Camus. Kwestia nihilizmu w twórczości eseistycznej i prozatorskiej Alberta Camusa sprowadza się do pytania o tożsamość albo pokrewieństwo „absurdu” i „nicości”. Francuski pisarz i filozof był przekonany o absurdalności istnienia. Stawiał jednak sobie i światu pewne wymagania aksjologiczne, pragnąc trud Syzyfa zastąpić dążeniem do egzystencji autentycznej według Karla Jaspersa. Camus za pierwszą czynność umysłu uważał odróżnienie prawdy od fałszu. Dostrzegając prawdopodobieństwo dokonania tej operacji zakładał, że istnieje możliwość sprzeciwu wobec absurdalności świata. Hipotetyczny nihilizm był dla niego zachętą do nieustającej aktywności poznawczej, konfrontowania swoich niekoniecznie immanentnych racji z różnymi ujęciami szeroko rozumianej filozofii życia, rodzajem intelektualnej gry legitymizującej status myśliciela i artysty. Antropologia francuskiego myśliciela była bliska wizji człowieka jednowymiarowego Herberta 
Marcusego. Człowiek zbuntowany to ten, który ucieka od swojej jednowymiarowości.

Ostatnim referatem było wystąpienie mgr. Pawła Marcina Mazanki z Uniwersytetu Kardynała Stefana Wyszyńskiego w Warszawie nt. Antropologia Johna F. Crosby'ego jako odpowiedź na wspótczesny nibilizm. Prelegent rozpoczął swoje wystąpienie od osobistych spostrzeżeń dotyczących własnej pracy psychoterapeutycznej. Podkreślił, że coraz częściej pacjenci skarżą się na bezsens życia, brak motywacji do działania, doświadczenie pustki i absurdalności istnienia. Austriacki psychiatra i psychoterapeuta Viktor Frankl twierdził, że należy szukać w kulturze przyczyn tego, z czym przychodzą pacjenci do gabinetów psychoterapeutycznych. Jedną z odpowiedzi na współczesny nihilizm jest antropologia amerykańskiego myśliciela Johna F. Crosby'ego, który uważa, że podstawowymi kategoriami bytu ludzkiego są podmiotowość, nieudzielność i przygodność. Crosby podkreśla znaczenie wymiaru moralnego czynów ludzkich i zwraca uwagę na rolę solidarności społecznej. Amerykański myśliciel opowiada się za personalistyczną wizją bytu ludzkiego. Osoba ludzka należy do samej siebie. Jest celem samym w sobie, nigdy zaś jedynie środkiem do realizacji innych celów. Personalistyczna wizja człowieka stanowi skuteczne antidotum na różne formy nihilizmu.

Na zakończenie obrad sympozjalnych, po wspólnej dyskusji i inspirującej wymianie zdań, zabrała głos prof. Ewa Podrez, która podziękowała prelegentom i wszystkim uczestnikom za udział w konferencji. Zwróciła także uwagę na konieczność dalszej współpracy między różnymi ośrodkami naukowymi krajowymi i zagranicznymi, która może przyczynić się do adekwatnej diagnozy filozoficznej współczesnych wyzwań kulturowych i cywilizacyjnych.

ANDRZEJ KOBYLIŃSKI

a.kobylinski@uksw.edu.pl

Uniwersytet Kardynała Stefana Wyszyńskiego w Warszawie, Instytut Filozofii

Wóycickiego 1/3, 01-938 Warszawa

DOI: 10.21697/spch.2019.55.1.41 